Egyptian Journal of Rabbit Science, 27 (2): 267- 288 (2017)

\title{
EFFECT OF DIETARY ARAK (Salvadora persica) AND SEASON INTERACTION ON PERFORMANCE OF PRE AND POST-SEXUAL MATURITY OF RABBIT MALES
}

\author{
M. A. El-Sawy*; Kh. A. A. Ali*; M.N.F. Hassanein*; Noha Tag El-Din, \\ ** and K.H. El-Kholy*** \\ (*) Depart. Of Rabbits Res., Anim. Prod. Res. Inst., Agric. Res. Cent., \\ Dokki, Giza, Egypt. \\ (**) Depart. Of Anim. Prod., Fac. of Agric., Damietta Univ., Damietta, Egypt. \\ (***) Depart. Of Poul. Prod., Fac. of Agric., Damietta Univ., Damietta, \\ Egypt.E-mail: elsawy1966@Gmail.com
}

The present study aimed to evaluate the interaction effects of Arak (Salvadora persica) as feed additive and season on performance of pre- and post-sexual maturity of rabbit males. Ninety-six weaned New Zealand White (NZW) male rabbits aged 30 days with weighing average $586.4 \mathrm{gm}$ (48 in each season) were used during winter and summer seasons. Within each season, two groups were used (24 in each group); the first group fed to ad libitum with commercial rabbit pellets and kept as control group, while the second group fed the same diet supplemented with 0.2\% dried Arak powder. Body weight, daily gain, daily feed intake and feed conversion were recorded from weaning up to 70 days of age. Whereas, four rabbits from each group were slaughtered and genitalia were immediately taken and dissected. Blood samples were collected at 150 days of age from five bucks from each group. At maturity age, several reproductive traits were recorded. Results showed that final body weight, daily weight gain, feed intake, feed conversion and weights of genital organs at 70 days of age significantly $(P \leq 0.05) \quad$ increased with dietary of Arak supplementation. Serum testosterone concentration at 150 days of age (maturity) significantly $(P \leq 0.01)$ increased with Arak inclusion during winter and summer seasons. The minimum maturity age was obtained by 0.2\% Arak inclusion during summer season (151 days). Sexual desire, mating activity, semen-ejaculate volume, advancedsperm motility\%, sperm-cell concentration and total-sperm output were significantly $(P \leq 0.01)$ affected by Arak inclusion, season and their interactions. 
Conclusively, from these results could be concluded that the addition of $0.2 \%$ Arak (Salvadora persica) to growing NZW male rabbit diets till sexual maturity age under winter and summer season improved growth and reproductive capabilities.

Key words: Rabbit males, Arak (Salvadora persica), reproductive organs, semen quality.

The environmental and nutritional factors are the important factors, which affect the economic of intensive rabbit production, under Egyptian conditions (Marai et al., 2006). In Egypt, due to the negative effects of heat stress of summer season on productive and reproductive performance, the annual breeding season of rabbits normally starts from October till May. Increasing of disease incidence, blood system impaired, mortality, fertility deterioration, reduced reproductive efficiency reduce are the most obvious sings of heat stress (Bani et al., 2005 and Marai et al., 2006), all of which adversely affect production economics. So that, using some natural nutrient additives were practiced to improve the productive and reproductive performances.

Several attempts have been made to improve rabbit production and reproduction using various commercial growth promoters (Ashour et al., 2004 and Osman Noha, 2005). Ibrahim et al., (2005), El-Kholy et al., (2008 a and b) and El-Sawy et al., (2014) showed that Arak can be used as an alternative growth promoter as it enhanced immune function and favored meat quality in growing rabbits.

Arak stems were obtained from the roots of Salvadora persica, which generally grows in the Middle East area; it has medicinal value in manifold uses and contains more than 10 different natural chemical compounds such as: fluoride, tannins, resins, alkaloids-Salvadoricine-, volatile oils -sinigrin-, sulfur, vitamin $\mathrm{C}$, sodium bicarbonate, chlorides, calcium, benzy liso thiocyanate and others, including silica-salicylic acid-, sterols, trime thylamine, saponins and flavonoid (Akhtar and Ajmal, 1981 and Hattab, 1997). Five flavonoid compounds (kaempferol, quercetin, quercetrin, rutin and quercetin glucoside) were isolated from the root of this plant (Islam et al., 2000). Flavonoids have antibacterial, astringent, detergent and abrasive properties (Almas and Stakiw, 2000 and Almas, 2002). Besides flavonoids, both polyphenolic compounds and certain alkaloids seem to stimulate immune function, reduce cholesterol level and play a role in the prevention of a number of chronic diseases such as cancer and cardiovascular disease in rabbits (Jeon et al., 2001 and Yousef et al., 2004). 
Therefore, purpose of the present study was to evaluate how various reproductive traits and the pre- and post-sexual maturity of NZW rabbit males are affected by season, including Arak (Salvadora persica) as a dietary feed additive and their interactions.

\section{MATERIALS AND METHODS}

\section{1- Location and seasons:}

The present work was carried out in a Rabbitry near El-Hawamdia City, Giza Province, Egypt, during cold season (December to February) and hot climate (June to August).

\section{2- Animals and feeding:}

A total number of 96 weaned males (30 days) average $586.4 \mathrm{gm}$ of New Zealand White rabbits (NZW) (48 in each season) were used during winter and summer seasons. Within each season, two groups were used (24 in each group). The first group was kept untreated to serve as a control, while the another group was fed the same diet supplemented with $0.2 \%$ dried Arak powder. The Arak roots of the plant were cut into small pieces and allowed to dry at room temperature for 2 days and were then ground to powder in a ball mill. Experimental rabbits were healthy and kept under the same management and hygienic conditions.

Rabbits fed ad libitum with commercial rabbit pellets containing $17.0 \%$ $\mathrm{CP}, 13.3 \% \mathrm{CF}$ and $2500 \mathrm{kcal} \mathrm{DE} / \mathrm{kg}$ diet according to NRC (1977). Chemical composition of Arak was determined in duplicate according to AOAC (2006), containing (\% DM): 27.9 ash, 12.4 crude protein, 1.75 ether extract, 50.0 nitrogen free extract and 7.95 crude fiber.

\section{3-Housing:}

Weaned bunnies were housed in metal cages with diameters of $40 \times 40 \times 30 \mathrm{~cm}$ (two bunnies/cage), while adult male rabbits were housed separately in individual cages with diameters of $50 \times 60 \times 35 \mathrm{~cm}$ of conventional universal galvanized wire batteries. All cages were equipped with feeding hoppers, which were made of galvanized steel sheets, and nipples for automatic drinking. The batteries were located in a well ventilated building. Averages of ambient temperature (AT, $\left.{ }^{\circ} \mathrm{C}\right)$, relative humidity (RH \%) were daily recorded, then, the temperature humidity index (THI units) was calculated using the equation proposed by Marai et al., (2001) as follow:

$$
\mathrm{THI}=\mathrm{db}{ }^{\circ} \mathrm{C}-\left[(0.31-0.31 \times \mathrm{RH} \%) \times\left(\mathrm{db}{ }^{\circ} \mathrm{C}-14.4\right)\right]
$$

Where: $\mathrm{db}{ }^{\circ} \mathrm{C}=$ Dry bulb temperature in Celsius, $\mathrm{RH} \%=$ Relative humidity percentage. 
The values obtained are then classified as absence of heat stress $(<27.8)$, moderate heat stress $(27.8-28.8)$, severe heat stress (28.9-29.9) and very severe heat stress $(\geq 30.0)$ as shown in Table 1 .

Table 1: Averages of ambient temperature (AT, $\left.{ }^{\circ} \mathrm{C}\right)$, relative humidity (RH $\%$ ) and temperature humidity index (THI units) during experimental period

\begin{tabular}{|c|l|c|c|c|}
\hline Season & Months & AT ( C ) & RH (\%) & THI (Units) \\
\hline \multirow{3}{*}{ Winter } & December & $18.0 \pm 0.44$ & $71.0 \pm 1.00$ & $17.7 \pm 0.43$ \\
\cline { 2 - 5 } & January & $19.5 \pm 0.45$ & $72.3 \pm 1.01$ & $19.1 \pm 0.44$ \\
\cline { 2 - 5 } & February & $20.2 \pm 0.42$ & $71.2 \pm 1.03$ & $19.7 \pm 0.44$ \\
\hline & Average & $\mathbf{1 9 . 2} \pm \mathbf{0 . 4 3}$ & $\mathbf{7 1 . 5} \pm \mathbf{1 . 0 2}$ & $\mathbf{1 8 . 8} \pm \mathbf{0 . 4 3}$ \\
\hline \multirow{3}{*}{ Summer } & June & $29.6 \pm 0.52$ & $69.3 \pm 0.61$ & $28.2 \pm 0.57$ \\
\cline { 2 - 5 } & July & $29.8 \pm 0.51$ & $71.0 \pm 0.57$ & $28.4 \pm 0.56$ \\
\cline { 2 - 5 } & August & $31.6 \pm 0.55$ & $68.5 \pm 0.68$ & $29.9 \pm 0.55$ \\
\hline & Average & $\mathbf{3 0 . 3} \pm \mathbf{0 . 5 3}$ & $\mathbf{6 9 . 6} \pm \mathbf{0 . 6 3}$ & $\mathbf{2 8 . 8} \pm \mathbf{0 . 5 6}$ \\
\hline
\end{tabular}

\section{Measurements:}

\section{1- At 70 days of age:}

Body weight (BW, g), daily body weight gain (DBWG, g) and daily feed intake (DFI, g) were recorded for each rabbit during the growing period from weaning (30 days of age) up to slaughtering commercial age (70 days of age). Feed conversion (FC) was calculated as a ratio of $\mathrm{g}$ feed/g gain.

Four growing rabbit males from each experimental group were randomly slaughtered (by bleeding). Genitalia were immediately taken after slaughter and dissections were performed. Weights of pituitary gland, testes, epididymis and sexual accessory glands were recorded. Their relative weights were expressed with respect to live body weight, as described by (Meshreky Samia et al., 2005).

\section{2- Blood parameters:}

2-1- At slaughter test:

Blood samples of growing rabbits were collected into dry clean centrifuge tubes during slaughter. Serum was separated by centrifugation at 3000 r.p.m. for 20 minutes and kept in a deep freezer at $-20{ }^{\circ} \mathrm{C}$ until biochemical analysis. Total protein (TP, g/dl); albumin (Alb, g/dl) were determined and globulin (Glob, g/dl) was obtained by subtracting the values of albumin from the corresponding values of total protein. The activities of 
alanine aminotransferase (ALT, U/l) and aspartate aminotransferase (AST, $\mathrm{U} / \mathrm{l})$ were estimated.

\section{2-2- At puberty and sexual maturity:}

At 150 days of age three $\mathrm{ml}$ of blood samples were collected between 08.00 and 09.00 am from the marginal ear vein of five bucks from each group. Serum was separated by centrifugation at 3000 r.p.m. for $20 \mathrm{~min}$ and kept at $-20{ }^{\circ} \mathrm{C}$ until hormonal assay. Serum testosterone $(\mathrm{T})(\mathrm{ng} / \mathrm{ml})$ hormone concentration of the rabbit males was determined using RIA kits (Immunotech, A Coulter Co., Czech Republic) in accordance with the manufacturer's information. The minimum detectable limit was $0.20 \mathrm{ng} / \mathrm{ml}$ and inter-\&-intra-assay coefficients of variation for $\mathrm{T}$ assay were 10.8 and $5 \%$, respectively. All samples were run in duplicate and assayed by the same operator, which was blind to the experimental situation.

\section{3- At sexual maturity:}

At sexual maturity (6 months), the body weight and age of fifteen rabbit bucks from each group were recorded. Scrotal circumference $(n=15$ rabbits per group) was measured by the method described by Boiti et al., (2005). Testicular index (length $\times$ width $\times$ depth) ( $n=15$ rabbits per group) was calculated in cubic centimeters as recorded by Castellini et al., (2006).

\section{4- Semen quality:}

Semen was artificially collected twice a week from ten bucks at 6 months of age for four weeks from each group by an artificial vagina as described by Boiti et al., (2005). Immediately after collection, semen ejaculate volume (ml), advanced sperm motility\%, live spermatozoa\%, morphological normal spermatozoa $\%$, acrosomal damages $\%$, sperm-cell concentration $\left(\mathrm{N} \times 10^{6} / \mathrm{ml}\right)$ and total-sperm output $\left(\mathrm{N} \times 10^{6} /\right.$ ejaculate $)$ were estimated according to Boiti et al., (2005) and Castellini et al., (2006). Libido (sexual desire) was assessed in terms of reaction time in seconds estimated from the time of introducing doe to the buck until the buck started to mount (Castellini et al., 2006). Mating activity (frequency of mating within 15 minutes) of ten bucks was determined using sexually receptive does.

\section{Statistical analysis:}

Data of the experiment was statistically analyzed according to SPSS (2012) computer program using the following fixed model:-

$$
\mathbf{Y}_{\mathbf{i j k}}=\boldsymbol{\mu}+\mathbf{S}_{\mathbf{i}}+\mathbf{T}_{\mathbf{j}}+\mathbf{S} \mathbf{T}_{\mathbf{i j}}+\mathbf{e}_{\mathbf{i j k}} \text {, }
$$

Where: $Y_{\mathrm{ijk}}=A n$ observation, $\mu=$ The overall mean, common element to all observations; $S_{i}=$ The fixed effect of the season $(i=1 \& 2) ; T_{j}=$ The fixed effect 
of treatment $(\mathrm{j}=1 \& 2) ; \mathrm{ST}_{\mathrm{ij}=}$ The interaction effect $(\mathrm{ij}=1,2,3,4) ; \mathrm{e}_{\mathrm{ijk}}=$ Random error component assumed to be normally distributed.

Data presented as percentages were transformed to the corresponding arcsine values (Warren and Gregory, 2005) before being statistically analyzed. The differences among means were tested using Duncan's New Multiple Range Test (Duncan, 1955).

\section{RESULTS AND DISCUSSION}

\section{Climatic conditions:}

Averages of AT, RH\% and THI units during the whole experimental period are shown in Table 1 . The THI values clearly indicated an absence of heat stress conditions (less than 27.8) during winter season. While during summer season rabbits were exposed to moderate heat stress (28.8). It was suggested that the optimal temperature humidity index for the rabbit husbandry is 27.8 (Marai et al., 2001).

\section{Productive and reproductive performances:}

\section{1- Growth performance:}

\section{1-1. Effect of season:}

Results in Table 2 showed significant differences $(\mathrm{P} \leq 0.05)$ between season groups in body weight, body weight gain (DBWG) and feed efficiency of weaned NZW rabbits. Elevating THI, during summer season significantly $(\mathrm{P} \leq 0.05)$ decreased growth performance traits and feed efficiency of growing NZW rabbits. These results agreed with those of Ondruska et al., (2011) and El-Sawy et al., (2014). On the other hand, Daader et al., (1999) reported that difference in BWG between winter and summer was not significant. However, feed intake decreased by $40-50 \%$ at 30-32 ${ }^{\circ} \mathrm{C}$ (Rafai and Papp, 1984 and Wittorf et al., 1988) and by $30 \%$ in summer than in winter (Marai et al., 1994) and in hot $\left(>32{ }^{\circ} \mathrm{C}\right)$ conditions (Hermes et al., 1999). The reduction of DFI under summer hot conditions in the present study may be due to that the high ambient temperature stimulates the thermal receptors center in the hypothalamus causing a decrease in feed intake as mentioned by Marai et al., (1994 and 2006). In contrast, the increased feed intake during winter may be due to the appetite increase of rabbits (Ashour et al., 2005). Exposure to high ambient temperature pushes rabbits to balance the excessive heat load by using different means to dissipate, as much as possible, their latent heat. If such means fail, rabbits use strategies that include: depression in feed intake (Okab et al., 2008). The reduction in BWG during summer season was due 
to a drastic decrease in rabbit FI and FC as compared with winter season, which might have led to less protein biosynthesis and less fat deposition (Okab et al., 2008 and Ogunjimi et al., 2008). In addition, Bahga et al., (2010) showed that heat stress leads to decreased performance of growing rabbits in terms of decreased growth rate and FI.

\section{1-2. Effect of Arak treatment:}

Data presented in Table 2 showed that, FBW, DBWG at 70 days, and feed conversion values of growing NZW rabbits fed diet supplemented with $0.2 \%$ Arak were significantly $(\mathrm{P} \leq 0.05)$ higher during winter and summer season as compared with control groups while, no effect was detected on DFI. These results are similar to that reported by Ibrahim et al., (2005); ElKholy et al., (2008a) and El-Sawy et al., (2014).

Table 2: Effect of Arak (Salvadora persica), season and their interaction inclusion on some growth performance traits of NZW rabbit males from 30 to 70 days of age

\begin{tabular}{|c|c|c|c|c|c|}
\hline \multirow{2}{*}{ Factors } & \multicolumn{5}{|c|}{ Parameters $^{1}$} \\
\cline { 2 - 6 } & IBW & FBW & DBWG & DFI & FC \\
\hline Season effect & $*$ & $* *$ & $* *$ & $*$ & $*$ \\
\hline Winter (W) & 606.34 & 1722.15 & 27.90 & 92.47 & 3.32 \\
& \pm 10.22 & \pm 17.71 & \pm 1.09 & \pm 2.53 & \pm 0.09 \\
\hline Summer (S) & 590.95 & 1552.99 & 24.05 & 85.31 & 3.55 \\
& \pm 11.75 & \pm 22.92 & \pm 1.30 & \pm 2.86 & \pm 0.09 \\
\hline Arak treatment effect & NS & $* *$ & $*$ & NS & $* *$ \\
\hline Control (C) & 599.79 & 1603.43 & 25.09 & 87.41 & 3.48 \\
& \pm 11.21 & \pm 18.04 & \pm 1.16 & \pm 2.74 & \pm 0.09 \\
\hline Treatment (T) & 597.50 & 1671.71 & 26.86 & 90.37 & 3.37 \\
& \pm 11.26 & \pm 20.60 & \pm 1.27 & \pm 2.77 & \pm 0.09 \\
\hline Interaction effects & $\mathbf{N S}$ & $* *$ & $* *$ & NS & $* *$ \\
\hline W $\times$ C & 607.63 & $1677.65^{\text {ab }}$ & $26.75^{\mathrm{b}}$ & 90.26 & $3.37^{\mathrm{bc}}$ \\
& \pm 17.03 & \pm 19.97 & \pm 1.40 & \pm 3.53 & \pm 0.01 \\
\hline $\mathrm{W} \times \mathrm{T}$ & 605.04 & $1766.65^{\mathrm{a}}$ & $29.04^{\mathrm{a}}$ & 94.68 & $3.26^{\mathrm{c}}$ \\
& \pm 11.70 & \pm 22.82 & \pm 1.62 & \pm 3.67 & \pm 0.01 \\
\hline $\mathrm{S} \times \mathrm{C}$ & 591.94 & $1529.21^{\mathrm{c}}$ & $23.43^{\mathrm{d}}$ & 84.56 & $3.61^{\mathrm{a}}$ \\
& \pm 14.26 & \pm 19.66 & \pm 1.68 & \pm 4.01 & \pm 0.01 \\
\hline $\mathrm{S} \times \mathrm{T}$ & 589.95 & $1576.77^{\mathrm{b}}$ & $24.67^{\mathrm{c}}$ & 86.06 & $3.49^{\mathrm{ab}}$ \\
& \pm 19.00 & \pm 31.57 & \pm 1.89 & \pm 4.16 & \pm 0.01 \\
\hline
\end{tabular}

${ }^{1}$ IBW: Initial body weight; FBW: Final body weight; BWG: Daily weight gain; FI: Daily feed intake; and FC: Feed conversion a,b,c Means with different letters within the same section and column differ significantly. NS= Not Significant; $*=\mathrm{P} \leq 0.05$; $* *=\mathrm{P} \leq 0.01$. 
The significant $(\mathrm{P} \leq 0.05)$ increase in DBWG for rabbits received Arak at $0.2 \%$ level could be due to the better absorption of protein (Ibrahim et al., 2005), bactericidal, antimycotic or antifungal properties of Arak as reported by Al-Samh and Al-Bagieh (1996). Also, vitamin C, which is presence in Arak, has important role in various metabolic processes in the body via its regulation effect on thyroid and adrenal glands functions (McDowell, 2000). This fact can explain the increase in LBW of treated groups. Beside that, sodium bicarbonate showing growth promoting response in most instances when included in diets of rabbits (Al-Shanti, 2003). On the other hand, the minerals content in Arak (calcium, fluorine, and sulphur) can form structural components of body organs and tissues (Suttle, 2010).

\section{1-3. Effect of interactions:}

Interactions between season and Arak supplementation effects were significant $(\mathrm{P} \leq 0.01)$ on FBW, DBWG and FC of NZW rabbits (Table 2). The magnitude of improvement was the highest with Arak treatment in winter. At the same time, there were a negative interaction effects of the Arak treatment on the DFI in the two seasons. It is interesting to observe the insignificant differences in FBW between treated rabbits under summer season $(\mathrm{S} \times \mathrm{T})$ and those untreated under winter season $(\mathrm{W} \times \mathrm{C})$. Beside that, Arak addition for rabbits reared, during summer season $(\mathrm{S} \times \mathrm{T})$ recorded insignificant differences in FC compared to those received the same treatment, under winter season $(\mathrm{W} \times \mathrm{T})$. The same pattern of these results was observed by El-Sawy et al., (2014). So, dietary addition of heat-stressed growing rabbits with $0.2 \%$ Arak restored the loss pertaining to heat stress and surpassed the winter control in DBWG, FC and FBW.

\section{Blood biochemical traits:}

\section{2-1. Effect of season:}

Blood biochemical parameters (within normal range) such as serum TP, Alb, Glob, ALT and AST were significantly $(\mathrm{P} \leq 0.05)$ higher in winter season than in summer one (Table 3). These changes in the blood biochemical parameters due to season effect was similar to that of Abdel-Monem et al., (2013) and El-Sawy et al., (2014) who found that blood biochemical traits were significantly lower $(\mathrm{P} \leq 0.01)$ in rabbits exposed to heat stress in summer season as compared to those reared in winter one.

The decrease in serum TP for weaned NZW rabbits in summer season group may be due to the decrease in DFI (as mentioned before) and dilution of serum proteins or both (Ondruska et al., 2011). They add that, the decrease in the protein synthesis can be due to a depression of anabolic hormonal 
Table 3: Effect of Arak (Salvadora persica), season and their interactions

\begin{tabular}{|l|c|c|c|c|c|}
\multicolumn{2}{c}{ on some blood metabolites of NZW rabbit males at 70 day of age } \\
\cline { 2 - 6 } & $\begin{array}{c}\text { Patal } \\
\text { Trotein } \\
\text { (TP,g/dl) }\end{array}$ & $\begin{array}{c}\text { Albumin } \\
\text { (Alb, } \\
\text { g/dl) }\end{array}$ & $\begin{array}{c}\text { Globulin } \\
\text { (Glob, } \\
\text { g/dl }\end{array}$ & $\begin{array}{c}\text { ALT } \\
(\mathbf{U} / \mathbf{l})\end{array}$ & $\begin{array}{c}\text { AST } \\
\text { (U/l) }\end{array}$ \\
\hline Season effect & $*$ & $*$ & $*$ & $*$ & $*$ \\
\hline Winter(W) & 7.81 & 5.25 & 2.56 & 16.43 & 25.30 \\
& \pm 0.50 & \pm 0.42 & \pm 0.13 & \pm 0.64 & \pm 1.73 \\
\hline Summer (S) & 6.32 & 4.15 & 2.17 & 14.16 & 22.36 \\
& \pm 0.28 & \pm 0.24 & \pm 0.09 & \pm 0.78 & \pm 1.15 \\
\hline Arak treatment effect & $*$ & $*$ & $*$ & $*$ & $*$ \\
\hline Control (C) & 6.60 & 4.36 & 2.25 & 14.25 & 21.49 \\
& \pm 0.31 & \pm 0.25 & \pm 0.12 & \pm 0.80 & \pm 1.57 \\
\hline Treatment (T) & 7.53 & 5.05 & 2.48 & 16.33 & 26.18 \\
& \pm 0.48 & \pm 0.41 & \pm 0.11 & \pm 0.62 & \pm 1.31 \\
\hline Interaction effects & $* *$ & $* *$ & $*$ & $*$ & $*$ \\
\hline $\mathrm{W} \times \mathrm{C}$ & $7.70^{\mathrm{a}}$ & $5.20^{\mathrm{a}}$ & $2.50^{\mathrm{a}}$ & $15.90^{\mathrm{a}}$ & $24.85^{\mathrm{a}}$ \\
& \pm 0.45 & \pm 0.35 & \pm 0.18 & \pm 0.96 & \pm 2.59 \\
\hline $\mathrm{W} \times \mathrm{T}$ & $7.92^{\mathrm{a}}$ & $5.30^{\mathrm{a}}$ & $2.62^{\mathrm{a}}$ & $16.95^{\mathrm{a}}$ & $25.75^{\mathrm{a}}$ \\
& \pm 0.90 & \pm 0.77 & \pm 0.18 & \pm 0.85 & \pm 2.37 \\
\hline $\mathrm{S} \times \mathrm{C}$ & $5.50^{\mathrm{c}}$ & $3.51^{\mathrm{c}}$ & $1.99^{\mathrm{b}}$ & $12.60^{\mathrm{b}}$ & $18.12^{\mathrm{b}}$ \\
& \pm 0.27 & \pm 0.19 & \pm 0.14 & \pm 1.19 & \pm 1.47 \\
\hline $\mathrm{S} \times \mathrm{T}$ & $7.13^{\mathrm{b}}$ & 4.79 & $2.34^{\mathrm{ab}}$ & $15.71^{\mathrm{a}}$ & $26.60^{\mathrm{a}}$ \\
& \pm 0.35 & \pm 0.31 & \pm 0.13 & \pm 0.91 & \pm 1.17 \\
\hline
\end{tabular}

a, b, c Means bearing different letters in the same column significantly differed within each factors $(\mathrm{P} \leq 0.05)$. NS $=$ Not Significant; $*=\mathrm{P} \leq 0.05 ; * *=\mathrm{P} \leq 0.01$.

secretion such as growth hormone, thyroxin and insulin. In addition, Amici and Merendino (1996) showed that the decrease of TP has to be considered as an important biological indicator of deficiency in activity of the immune system function in heat stressed rabbits.

Serum ALT and AST means were significantly higher during winter than summer that may be related with feed intake, which has the same trend. The more feed intake provides the body with more amino acids by protein digestion. This result came in harmony with El-Maghawry et al., (2000) who found that ALT and AST are dependent on alanine and glutamine taken by the liver and reflect metabolism changes in liver which associated with glucose synthesis. 


\section{2-2. Effect of Arak treatment:}

The effect of treatment with Arak during winter and summer on some blood parameters were presented in Table 3. The data showed that treatment with Arak significantly $(\mathrm{P} \leq 0.05)$ increased serum TP and its fractions (Alb and Glob) and liver enzymes of ALT and AST as obtained by Ibrahim et al., (2005) and El-Kholy et al., (2008b). Arak (Salvadora persica) includes some immunity stimulators such as flavenoids, polyphenolic compounds and certain alkaloids (Fortun-Lamothe and Drouet-Viard, 2002). The important biochemical indices that can be used to assess the health status of the liver are the serum levels of alb and glob. Albumin, which was manufactured by the liver, is a major protein that circulates in the blood stream (Tietz, 1986). Increasing serum TP and their fractions (Alb and Glob) within the normal range may reflect an increase in the hepatic function (El-Harairy et al., 2003). This phenomenon was observed in treated groups as compared to control group. As mentioned before, Arak increased the levels of ALT and AST but both increases were still within the normal ranges as indicated by the non-sign of toxicity. In addition, the increased values of blood biochemical traits in the treated groups as mentioned later, may be the reason of increased growth performance, whereas, Al-Eissa (2011) showed that biochemical parameters could be used to assess the metabolic condition of rabbits.

\section{2-3. Effect of interactions:}

It is evident from Table 3 that each of TP, Alb, Glob, ALT and AST significantly $(\mathrm{P} \leq 0.01$ and $\mathrm{P} \leq 0.05)$ affected by season $\times$ treatment interaction and the highest estimates were by $\mathrm{W} \times \mathrm{T}$ and the lowest ones were by $\mathrm{S} \times \mathrm{C}$. These results were in a good agreement with those of Ibrahim et al., (2005) and El-Kholy et al., (2008a). The increase in globulin concentration with Arak inclusion in the heat stressed rabbit's diet as observed in the present study may be an indication of increased immunity in the rabbits since the liver will be able to synthesize enough globulins for immunologic action as mentioned by Sunmonu and Oloyede (2007). Increase of glob concentration than alb is important for immunologic responses (Tietz, 1986).

\section{Genitalia traits at 70 days of age:}

\section{3-1. Effect of season:}

Table 4 revealed that, season had high significant effect $(\mathrm{P} \leq 0.01)$ on FBW and all internal genitalia organs weight, except that insignificant effect on REW. Where, all those means were higher in winter than summer. These the increase in growth performance. Therefore, pre-slaughter weight is 
EFFECT OF DIETARY ARAK \& SEASON INTERACTION ON RABBITS

Table 4: Effect of Arak (Salvadora persica), season, and their interaction on body and internal genitalia organs weights of NZW rabbit males at 70 days of age

\begin{tabular}{|c|c|c|c|c|c|c|c|c|c|}
\hline \multirow[t]{2}{*}{ Factors } & \multicolumn{9}{|c|}{ Parameters ${ }^{1}$} \\
\hline & FBW & $\begin{array}{c}\text { TW } \\
\text { g }\end{array}$ & $\begin{array}{c}\text { RTW } \\
\%\end{array}$ & $\begin{array}{c}\mathbf{E W} \\
\mathbf{g}\end{array}$ & $\begin{array}{c}\text { REW } \\
\%\end{array}$ & $\begin{array}{c}\text { SGW } \\
\text { g }\end{array}$ & $\begin{array}{c}\text { RSGW } \\
\%\end{array}$ & $\begin{array}{c}\text { PGW } \\
\text { g }\end{array}$ & $\begin{array}{c}\text { RPGW } \\
\%\end{array}$ \\
\hline Season & $*$ & $*$ & $*$ & $*$ & $\mathbf{N S}$ & $*$ & * & $*$ & $*$ \\
\hline Winter (W) & $\begin{array}{l}1703.63 \\
\pm 22.25\end{array}$ & $\begin{array}{c}5.60 \\
\pm 0.19\end{array}$ & $\begin{array}{l}0.329 \\
\pm 0.01\end{array}$ & $\begin{array}{c}1.02 \\
\pm 0.16\end{array}$ & $\begin{array}{c}0.06 \\
\pm 0.04\end{array}$ & $\begin{array}{c}3.48 \\
\pm 0.18\end{array}$ & $\begin{array}{l}0.204 \\
\pm 0.04\end{array}$ & $\begin{array}{c}3.24 \\
\pm 0.13\end{array}$ & $\begin{array}{l}0.199 \\
\pm 0.07\end{array}$ \\
\hline $\begin{array}{l}\text { Summer } \\
\text { (S) }\end{array}$ & $\begin{array}{l}1553.13 \\
\pm 37.41\end{array}$ & $\begin{array}{c}4.40 \\
\pm 0.37\end{array}$ & $\begin{array}{l}0.282 \\
\pm 0.02\end{array}$ & $\begin{array}{c}0.79 \\
\pm 0.15\end{array}$ & $\begin{array}{c}0.05 \\
\pm 0.07\end{array}$ & $\begin{array}{c}2.86 \\
\pm 0.22\end{array}$ & $\begin{array}{l}0.184 \\
\pm 0.06\end{array}$ & $\begin{array}{c}2.89 \\
\pm 0.24\end{array}$ & $\begin{array}{l}0.173 \\
\pm 0.08\end{array}$ \\
\hline Treatment: & $*$ & $*$ & $*$ & $*$ & $*$ & $*$ & $*$ & $* *$ & $*$ \\
\hline Control (C) & $\begin{array}{c}1591.75 \\
\pm 69.17\end{array}$ & $\begin{array}{c}447 \\
\pm 0.47\end{array}$ & $\begin{array}{l}0.279 \\
\pm 0.02\end{array}$ & $\begin{array}{c}0.82 \\
\pm 0.09\end{array}$ & $\begin{array}{c}0.05 \\
\pm 0.04\end{array}$ & $\begin{array}{c}2.98 \\
\pm 0.20\end{array}$ & $\begin{array}{l}0.187 \\
\pm 0.06\end{array}$ & $\begin{array}{c}2.99 \\
\pm 0.21\end{array}$ & $\begin{array}{l}0.175 \\
\pm 0.08\end{array}$ \\
\hline $\begin{array}{l}\text { Treatment } \\
\text { (T) }\end{array}$ & $\begin{array}{l}1665.00 \\
\pm 47.44\end{array}$ & $\begin{array}{c}5.52 \\
\pm 0.24\end{array}$ & $\begin{array}{l}0.332 \\
\pm 0.06\end{array}$ & $\begin{array}{c}0.99 \\
\pm 0.10\end{array}$ & $\begin{array}{c}0.6 \\
\pm 0.05\end{array}$ & $\begin{array}{c}3.36 \\
\pm 0.07\end{array}$ & $\begin{array}{l}0.202 \\
\pm 0.04\end{array}$ & $\begin{array}{c}3.13 \\
\pm 0.10\end{array}$ & $\begin{array}{l}0.197 \\
\pm 0.06\end{array}$ \\
\hline Interactions & $* *$ & $* *$ & $* *$ & $*$ & $\mathrm{NS}$ & $* *$ & $*$ & $* *$ & $*$ \\
\hline $\mathrm{W} \times \mathrm{C}$ & $\begin{array}{c}1672.25^{\mathrm{a}} \\
\pm 40.61\end{array}$ & $\begin{array}{l}5.35^{\mathrm{a}} \\
\pm 0.32\end{array}$ & $\begin{array}{l}0.320^{\mathrm{a}} \\
\pm 0.02\end{array}$ & $\begin{array}{l}0.92^{\mathrm{a}} \\
\pm 0.07\end{array}$ & $\begin{array}{c}0.06 \\
\pm 0.05\end{array}$ & $\begin{array}{l}3.33^{\mathrm{b}} \\
\pm 0.11\end{array}$ & $\begin{array}{l}0.199 \\
\pm 0.05\end{array}$ & $\begin{array}{l}3.16^{\mathrm{ab}} \\
\pm 0.17\end{array}$ & $\begin{array}{c}0.189^{\mathrm{ab}} \\
\pm 0.01\end{array}$ \\
\hline $\mathrm{W} \times \mathrm{T}$ & $\begin{array}{c}1735.00^{\mathrm{a}} \\
\pm 22.25\end{array}$ & $\begin{array}{l}5.85^{\mathrm{a}} \\
\pm 0.22\end{array}$ & $\begin{array}{l}0.337^{\mathrm{a}} \\
\pm 0.09\end{array}$ & $\begin{array}{l}1.11^{\mathrm{a}} \\
\pm 0.09\end{array}$ & $\begin{array}{c}0.06 \\
\pm 0.05\end{array}$ & $\begin{array}{l}3.63^{\mathrm{b}} \\
\pm 0.11\end{array}$ & $\begin{array}{l}0.209^{\mathrm{a}} \\
\pm 0.05\end{array}$ & $\begin{array}{l}3.31^{\mathrm{a}} \\
\pm 0.10\end{array}$ & $\begin{array}{l}0.208^{\mathrm{a}} \\
\pm 0.07\end{array}$ \\
\hline $\mathrm{S} \times \mathrm{C}$ & $\begin{array}{c}1511.25^{\mathrm{b}} \\
\pm 50.84\end{array}$ & $\begin{array}{l}3.60^{b} \\
\pm 0.15\end{array}$ & $\begin{array}{l}0.238^{\mathrm{b}} \\
\pm 0.01\end{array}$ & $\begin{array}{l}0.73^{\mathrm{b}} \\
\pm 0.11\end{array}$ & $\begin{array}{c}0.05 \\
\pm 0.07\end{array}$ & $\begin{array}{l}2.63^{\mathrm{a}} \\
\pm 0.21\end{array}$ & $\begin{array}{l}0.174^{b} \\
\pm 0.09\end{array}$ & $\begin{array}{l}2.82^{\mathrm{b}} \\
\pm 0.16\end{array}$ & $\begin{array}{l}0.160^{b} \\
\pm 0.08\end{array}$ \\
\hline $\mathrm{S} \times \mathrm{T}$ & $\begin{array}{c}1595.00^{\mathrm{ab}} \\
\pm 28.94\end{array}$ & $\begin{array}{l}5.20^{\mathrm{a}} \\
\pm 0.20\end{array}$ & $\begin{array}{l}0.326^{\mathrm{a}} \\
\pm 0.06\end{array}$ & $\begin{array}{l}0.86^{\mathrm{a}} \\
\pm 0.29\end{array}$ & $\begin{array}{c}0.05 \\
\pm 0.01\end{array}$ & $\begin{array}{l}3.09^{b} \\
\pm 0.10\end{array}$ & $\begin{array}{l}0.194^{\mathrm{ab}} \\
\pm 0.07\end{array}$ & $\begin{array}{l}2.95^{\mathrm{ab}} \\
\pm 0.15\end{array}$ & $\begin{array}{c}0.185^{\mathrm{b}} \\
\pm 0.09\end{array}$ \\
\hline
\end{tabular}

FBW: Final body weight; TW: Testes weight (g); RTW: Relative testes weight; EW: Epididymis weight (g); REW: Relative epididymis weight; SGW: Sexual-accessory glands weight (g); RSGW: Relative sexual-accessory glands weight; PGW:, Pituitary gland weight (g); RPGW: Relative pituitary gland weight.

a,b,c Means bearing different letters in the same column significantly differed within each factors $(\mathrm{P} \leq 0.05)$. NS $=$ Not Significant; $*=\mathrm{P} \leq 0.05 ; * *=\mathrm{P} \leq 0.01$.

findings are in agreement with Meshreky Samia et al., (2005). These might be due to reduced testosterone levels (Table 5) or feed consumption and deterioration of DBWG (Table 2) resulted in stressful hot conditions during summer season.

\section{3-2. Effect of Arak treatment:}

Table 4 showed that values of relative weights of testes, epididymis and sexual-accessory gland weight increased significant $(\mathrm{P} \leq 0.05)$ with dietary Arak inclusion. These results were similar to those observed in mice where the inclusion of $800 \mathrm{mg} / \mathrm{kg}$ of an extract of Salvadora persica (Arak) increased the relative weight of the testes (Darmani, 2003). The increase in internal genitalia organs weights for treated group may be mainly related to 
considered to be one of the most important factors affecting on internal genitalia organs weight in rabbits.

\section{3-3. Effect of interactions:}

Concerning, season and dietary of Arak supplementation interactions, it is clear that treated rabbits with Arak led to insignificant differences between both of seasons for each values of relative weights of testes, sexual-accessory glands and pituitary gland (Table 4). Moreover, these values did not differ than that of $(\mathrm{W} \times \mathrm{C})$ group. This result is another evidence of the privilege of Arak during summer season than the winter season.

\section{Reproductive performance at maturity: \\ 4-1. Effect of season:}

Results in Table 5 showed significant differences $(\mathrm{P} \leq 0.05)$ among season groups for weight and age at maturity, testicular index and testosterone concentration at 150 days of age for male NZW rabbits. These results agreed with those of Meshreky Samia et al., (2005). The adverse effect of summer season on late of age at maturity, testicular index and testosterone concentration may be related to decrease on relative of testes weight for rabbits reared under summer season. El-Sobhy (2000) found that the testes of heat exposed animal's revealed significant focal degeneration in both seminiferous tubules and interstitial cells. However, Katongola et al., (1974) reported that decline in testosterone level during summer season causing disorders in accessory glands secretion and spermatogenesis. In addition, Jegou et al., (1984) mentioned that the reduction in testosterone level during summer season resulted from reduction in the ability of leydig and sertoli cells responding to luteinzing hormone.

\section{4-2. Effect of Arak treatment:}

The early maturity age was recorded with Arak groups either in winter or in summer seasons (Table 5). This result could be related to the maximum final body weight obtained with Arak dietary and also to the improving effect of Arak on testosterone concentration that leads to faster maturity. The early of age at maturity observed in the present results were similar to that observed in previous studies in rabbits with either other growth promoters (Amin et al., 2002 and Marai et al., 2006) or Arak supplementation (El-Kholy et al., 2008a). Similar results were obtained by Meshreky Samia et al., (2005), who found that age at maturity was related to testosterone concentration. 
Table 5. Effect of Arak (Salvadora persica), season and their interaction on some reproductive traits of NZW rabbit bucks at 150 days of age

\begin{tabular}{|c|c|c|c|c|c|}
\hline \multirow{2}{*}{ Factors } & \multicolumn{5}{|c|}{ Parameters } \\
\cline { 2 - 6 } & $\begin{array}{c}\text { Weight at } \\
\text { maturity } \\
(\mathbf{g})\end{array}$ & $\begin{array}{c}\text { Age at } \\
\text { maturity } \\
(\mathbf{d a y})\end{array}$ & $\begin{array}{c}\text { Scrotal } \\
\text { circumference, } \\
(\mathbf{c m})\end{array}$ & $\begin{array}{c}\text { Testicular } \\
\text { index } \\
\left(\mathbf{c m}^{3}\right)\end{array}$ & $\begin{array}{c}\text { Testosterone, } \\
\text { ng/mL }\end{array}$ \\
\hline Season & $*$ & $*$ & NS & $* *$ & $*$ \\
\hline Winter $(\mathrm{W})$ & 2802.47 & 153.37 & 7.18 & 5.99 & 4.48 \\
& \pm 14.28 & \pm 0.87 & \pm 0.06 & \pm 0.13 & \pm 0.26 \\
\hline Summer & 2715.50 & 162.87 & 7.07 & 5.28 & 3.61 \\
$(\mathrm{~S})$ & \pm 40.11 & \pm 4.01 & \pm 0.07 & \pm 0.22 & \pm 0.32 \\
\hline Treatment: & $*$ & $* *$ & $*$ & $* *$ & $* *$ \\
\hline Control $(\mathrm{C})$ & 2717.20 & 164.27 & 7.02 & 21.48 & 3.40 \\
& \pm 40.05 & \pm 3.86 & \pm 0.05 & \pm 1.57 & \pm 0.26 \\
\hline Treatment & 2800.77 & 151.97 & 7.23 & 26.18 & 4.68 \\
$(\mathrm{~T})$ & \pm 14.79 & \pm 0.92 & \pm 0.07 & \pm 1.31 & \pm 0.30 \\
\hline Interactions & $*$ & $* *$ & $\mathrm{NS}$ & $* *$ & $* *$ \\
\hline $\mathrm{W} \times \mathrm{C}$ & $2774.60^{\mathrm{ab}}$ & $154.53^{\mathrm{b}}$ & 7.10 & $5.74^{\mathrm{b}}$ & $4.15^{\mathrm{b}}$ \\
& \pm 18.87 & \pm 1.08 & \pm 0.07 & \pm 0.16 & \pm 0.32 \\
\hline $\mathrm{W} \times \mathrm{T}$ & $2830.33^{\mathrm{b}}$ & $152.20^{\mathrm{b}}$ & 7.25 & $6.25^{\mathrm{b}}$ & $4.80^{\mathrm{b}}$ \\
& \pm 19.43 & \pm 1.34 & \pm 0.09 & \pm 0.17 & \pm 0.40 \\
\hline $\mathrm{S} \times \mathrm{C}$ & $2659.80^{\mathrm{a}}$ & $168.63^{\mathrm{a}}$ & 6.93 & $4.46^{\mathrm{a}}$ & $2.66^{\mathrm{a}}$ \\
& \pm 76.28 & \pm 6.87 & \pm 0.07 & \pm 0.19 & \pm 0.35 \\
\hline $\mathrm{S} \times \mathrm{T}$ & $2771.20^{\mathrm{ab}}$ & $157.10^{\mathrm{b}}$ & 7.20 & $6.09^{\mathrm{b}}$ & $4.55^{\mathrm{b}}$ \\
& \pm 20.11 & \pm 1.30 & \pm 0.11 & \pm 0.17 & \pm 0.46 \\
\hline
\end{tabular}

a,b,c Means bearing different letters in the same column significantly differed within each factors $(\mathrm{P} \leq 0.05) . \quad \mathrm{NS}=$ Not Significant; $*=\mathrm{P} \leq 0.05 ; * *=\mathrm{P} \leq 0.01$.

The increase in serum testosterone concentration in treated groups can be attributed mainly to the increase in sexual accessory gland activity with dietary Arak inclusion (El-Kholy, 2008a). This can affect the secretion of testosterone from the interstitial tissues of the testes (Al-Sobayil and Khalil, 2002). Also, Castro et al., (2002) mentioned that testosterone is needed to initiate spermatogenesis at puberty and for the maintenance of this process in the adult. El-Sherbiny (1994) found that the onset of puberty involves the appearance of the first spermatozoa in the caudal epididymis of rabbit males. Moreover, the testicular index significantly increased $(\mathrm{P} \leq 0.05)$ in treated group as compared to control one (Table 5), obtaining a maximum value at winter season. Testicular size is the best primary assessment of spermatogenesis, since the tubules and germinal elements account for approximately $98 \%$ of the testicular mass (Sherines and Howards, 1978). The testicular index also reflects spermatogenesis and testosterone 
production (El-Mougy et al., 1991). Arak inclusion had a significant effect on scrotal circumference (Table 5).

\section{4-3. Effect of interactions:}

The interaction effects between season and treatment groups were significant on weight and age at maturity, testicular index and testosterone concentration, while it was insignificant on scrotal circumference (Table 5). It was also observed that the insignificant differences were found among $(\mathrm{W} \times \mathrm{C}),(\mathrm{W} \times \mathrm{T})$ and $(\mathrm{S} \times \mathrm{T})$ groups for weight and age at maturity and testicular index. These results could be a reflection of testosterone concentration, which had the same trend. So, this is sufficient to prove that Arak addition was more efficient and beneficial under the Egyptian summer condition.

\section{Libido, mating activity and physical semen quality:}

\section{5-1. Effect of season:}

It is evident from Table 6 that the libido, mating activity and the physical semen quality of NZW rabbit bucks during the winter season were highly significant $(\mathrm{P} \leq 0.01)$ better than those observed in the summer season. These results agree with the findings of Safaa et al., (2008) and Lavara et al., (2013). It was established that semen volume increased and motility indexes decreased during summer (Roca et al., 2005). Also, Finzi et al., (1995) reported that the daily exposure of rabbits in a climatic chamber to high ambient temperature $\left(30^{\circ} \mathrm{C}\right)$ and humidity $(70 \%)$ for $21 \mathrm{hr}$ over a 60 days period increased the number of abnormal spermatozoa. Mate rabbits are extremely sensitive to heat stress therefore a rise in testicular temperature in rabbits leads to reduced spermatogenesis; temporary sterility; decreased sexual desire, ejaculate volume, motility, sperm concentration, and total number of spermatozoa in an ejaculate; and increased sperm abnormalities and dead sperm (Marai et al., 2001).

\section{5-2. Effect of Arak treatment:}

As regard to Table 6 the treatment effects were significant $(\mathrm{P} \leq 0.01)$ on all studied traits where the lowest values were for libido and acrosomal damage while the highest values were for mating activity, semen-ejaculate volume, advanced-sperm motility, live spermatozoa, morphological normal spermatozoa, sperm-cell concentration and total-sperm output, respectively. These increases are close to those obtained by El-Kholy et al., (2008a). 
The increase in sexual accessory gland weight in treated rabbits (Table 4) suggests that an increase in ejaculate volume occurred, since the accessory glands and spermatogenesis are controlled by the testosterone concentration, which was higher in treated rabbits. The observed effects on sperm concentrations and motility in the present trial are in agreement with those of Fields et al., (1979), who observed that sperm concentration was positively correlated with motility and testicular size in young bulls. The decrease in acrosomal damage in the treated groups could be attributed to the antioxidant activity of Arak due to flavonoids, which can protect the plasma membrane that surrounds the acrosome and the tail. Accordingly, it seems that Arak may display an indirect role in rabbit spermatogenesis.

\section{5-3. Effect of interactions:}

Arak treatment $\times$ season interaction had significant $(\mathrm{P} \leq 0.01)$ effect on libido, mating activity and all physical semen quality. Untreated rabbit bucks during the summer season had the lower $(\mathrm{P} \leq 0.01)$ values of libido, mating activity, semen-ejaculate volume, advanced-sperm motility, live spermatozoa, morphological normal spermatozoa, sperm-cell concentration and total-sperm output, respectively while the higher $(\mathrm{P} \leq 0.01)$ value of acrosomal damage than the other three interactions as shown in Table 6. It is interesting to see the insignificant differences between the treated rabbit bucks during summer season and the untreated one during winter in mating activity, semenejaculate volume, advanced sperm motility and live spermatozoa. This is another confirmation that treatment with Arak was more efficient and beneficial during summer season rather than winter season.

Conclusively, it could be concluded that dietary supplementation of NZW growing rabbit males till sexual maturity with $0.2 \%$ Arak powder improved some production and physical semen characteristics especially in the hot period of the year in Egypt.

\section{REFERENCES}

Abdel-Monem, U.M., Huda, Qar and Kandeil, M.A. (2013). Hot climate effects and their amelioration on growth performance, carcass traits, blood constituents and picture of growing kids. J. Appl. Sci. Res., 9: 666671.

Akhtar M.S. and Ajmal M. (1981). Significance of chewing sticks (miswaks) in oral hygiene from a pharmacological viewpoint. J. Pak. Med. Assoc., 31, 89-95. 
Al-Eissa, M. S. (2011). Effect of gestation and season on the haematological and biochemical parameters in domestic rabbit (Oryctolagus cuniculus). British Biotechnol. J., 1: 10-17.

Almas K., (2002). The effect of Salvadora persica extract (Miswak) and chlorhexidine gluconate on human dentin: A SEM Study. J. Contemp. Dent. Pract., 3: 27-35.

Almas K., and Stakiw J.E. (2000). The effect of miswak extract from Salvadora persica stored for 18 years on microbes in vitro. Egyptian Dent. J, 46: 227-30.

Al-Samh, D.A.A. and Al-Bagieh, N.H. (1996). A study of the antimicrobial activity of the miswak ethanolic extract in vitro. Biomedical Letters, 53: 212-238.

Al-Shanti, H. (2003). Using Vitamin C and sodium bicarbonate to alleviate the effects of heat stress on rabbit performance. Egyptian Poultry Sci. J., 23: 129-139.

Al-Sobayil K., and Khalil M.H. (2002). Semen characteristics of bucks in crossbreeding project involving Saudi Gabali with V-Line rabbits in Saudi Arabian. 3rd Sci. Conf. Rabbit Prod. in Hot Climates, Hurghada, Egypt, October, 117-126.

Amici, A. and Merendino, M. (1996). Some metabolic and immunological parameters in rabbits as affected by prolonged thermal stress. 6th World Rabbit Congress, Toulouse, France, 2: 147-150.

Amin S.O., Tharwat, E.E., El-Sherbiny A.M., Shaker Y.M., and Mekkawy M.Y.A., (2002). Reproductive performance of growing female New Zealand White rabbits treated with $\mathrm{GnRH}$ analogue and growth promoter. 3rd Sci. Conf. Rabbit Prod. in Hot Climates, Hurghada, Egypt, October, 301-316.

AOAC, (2006). Association of Official Analytical Chemists. Official Methods of Analysis 18th ed., Maryland, USA.

Ashour G., Ibrahim S.A., Ismail A.M., and El-Kholy K.H. (2004). Physiological reactions and biological performance of rabbits to summer heat stress. In Proc.: 2nd Sci. Conf. on Physio. Resp. to Environ. Condi., El-Arish, Egypt, July, 165-186.

Ashour, G.; A.A. Sedki and K.H. El-Kholy (2005). Efficiency of housing establishment for rabbits' productivity. The $4^{\text {th }}$ Inter. Con. on Rabbit Prod. in Hot Clim., 24-27 February 2005, Sharm El-Sheikh, Egypt, 425-434.

Bahga, C.S., Preetinder Kaur and M.C. Handa (2010). Performance of meat and wool type rabbits as affected by heat stress and microclimatic modification. Indian J. Anim. Res., 44: 67 - 69. 
Bani, P., Piccioli Cappelli, F., Minuti, A. and Abbatangelo, M. (2005). Variations of some blood parameters in rabbit reared under different environmental conditions. Ital. J. Anim. Sci., 4: 535-537.

Boiti, C.; Guelfi, G.; Brecchia, G.; Dall, A.C.; Ceccarelli, P.; Maranesi, M.; Mariottini, C.; Zampini, D.; Gobbetti, A. and Zerani, M. (2005). Role of endothelin-1 system in the luteolytic process of pseudopregnant rabbits. Endocrinology, 146: 1293-1300.

Castellini C., Besenfelder U., Pizzi F., Theau-Clément M., Vicente J.S.A., Renieri T. (2006). Recent knowledge on rabbit semen and buck management. In: Recent Advances in Rabbit Sciences (EU- Cost) Ed. Maertens L., Coudert P., 53-67.

Castro A.C.S., Berndtson W.E., and Cardoso F.M. (2002). Plasma and testicular testosterone levels, volume density and number of leydig cells and spermatogenic efficiency of rabbits. Braz. J. Med. Biol. Res., 35, 493-498.

Daader, A.H., Gabr, H.A. and Seleem, T.S. (1999). Productive and reproductive performance of New Zealand White and Californian rabbit Bucks as affected by supplementing vitamin A to the diet during summer and winter seasons. In Proc.: $7^{\text {th }}$ Conf. on Anim. Nutr. (Ruminants, Poultry and Fishes), 19-21 October, 1999, El-Arish, North-Sinai, Egypt, pp. $551-564$.

Darmani H., (2003). The effect of an extract of Salvadora persica (Meswak, chewing stick) on fertility of male and female mice. Int. J. Phytotherapy \& Phytopharmacology, 10, 62-66.

Duncan, D. B. (1955). Multiple range and multiple F. test. Biometrics, 11: 1-42.

El-Harairy, M.; M. Ayek and M.E. Omar (2003). Changes of some blood constituents and histological structure of liver, kidney and testes of growing rabbits in response to partial replacement of dietary protein. $9^{\text {th }}$ Conf. on Animal Nutrition (Ruminants, Poultry, Rabbit and Fish Nutrition), 14-17 October, 2003, Hurghada, Egypt, pp. 267-276.

El-Kholy, K.H., Seleem, T.S.T, El-Aasar, T.A. and Hanaa Abdelharith (2008a). Effect of dietary addition of Arak (Salvadora persica) on growth and reproductive performance in Black Baladi rabbit males. World Rabbit Science, 16: 21-27.

El-Kholy, K.H., T.A. El-Aasar, Hanaa Abdelharith and S.Z. El-Damrawy (2008b). Some physiological and immunological responses of rabbits fed diets contained Salvadora persica. Egyptian Journal of Rabbit Science, 18 (1) $15-29$. 
El-Maghawry, A.M.; A.M. Soliman; GH.A. El-Sayiad and KH. M. Mahrose (2000). Effects of breed, season of kindling and pregnancy status on some blood measurements of doe rabbits raised in Egypt. In: Egypt. J. Rabbit Sci., vol. 10, 2000, p. 295-306.

El-Mougy S.A., Abdel-Aziz S.A., Al-Shanawany M., and AbDallah O. (1991). The gonadotropic activity of Palmae in mature male rats. Alexandria J. Pharmacol., 5, 156-159.

El-Sawy, M. A.; Kh. A. A. Ali; M. N. F. Hassanein and K.H. El-Kholy (2014). Effect of interaction between season and Arak (Salvadora persica) supplementation on rabbits: 1- productive and some physiological performance of growing rabbits. J. Agric. Sci. Mansoura Univ., 7 (5): 249- 267.

El-Sherbiny A.M. (1994). Some reproductive aspects of male rabbits. Ph. D. Thesis, Ain Shams Univ., Cairo, Egypt.

El-Sobhy, H.E. (2000). Physiological responses and histochemical changes of some endocrine glands of NZW rabbit bucks exposed to $34^{\circ} \mathrm{C}$. Egyptian J. Rabbit Sci., 10: 19-41.

Fields M.J., Burns W.C. and Warnick A. C. (1979). Age, season and breed effects on testicular volume and semen traits in young beef bulls. Animal Sci., 48: 1299-1304.

Finzi A., Morera P., and Kuzminsky G. (1995). Sperm abnormalities as possible indicators of rabbit chronic heat stress. World Rabbit Sci., 3, $157-161$.

Fortun-Lamothe, L. and Drouet-Viard, F. (2002). Review: II- Diet and immunity current state of knowledge and research prospects for the rabbit. World Rabbit Sci., 10:25-399.

Hattab F.N. (1997). Muswak: the natural toothbrush. J. Clin. Dent., 8, 125-129.

Hermes, I.H., Ahmed, B.M., Khalil, M.H., Salah, M.S. and Al-Homidan, A.A. (1999). Growth performance, nutrients utilization and carcass traits of growing Californian rabbits raised under different ambient temperatures. Egyptian J. Rabbit Sci., 9: 117-138.

Ibrahim S.A.M.; Zanaty G.A. and Abdel-Azim A. (2005). Miswak and Khella as growth promoters in rabbits performance and some physiological aspects. Egyptian J. Poultry Sci., 25, 735-748.

Islam, M.W., Zakaria, M.N.M., Radhakrishnan, R., Liu, X.M., Chan K. and Al-Attas, A. (2000). Anti-gastric ulcer and cytoprotective properties of Aarak tree (Salvadora persica) and Purslane (Portulaca oleracea) in rats. In Proc.: British Pharmaceutical Conf., Birmingham, England, pp. 301-308. 
Jegou, B., D.M. Laws and D.E. Kretser (1984). Changes in testicular function induced by short term exposure of the germ cells, sertoli cells and leydig cells. Int. J. Andr., 7: 244.

Jeon, S. M., Bok, S.H., Jang, M.K., Lee, M.K., Nam, K.T., Park, Y.B., Rhee, S.J. and Choi, M.S. (2001). Antioxidative activity of naringin and lovastatin in high cholesterol-fed rabbits. Life Science, 2:2855-2866.

Katongola, C.B., F. Naftolin and R.V. Short (1974). Seasonal variations in blood luteinzing hormone and testosterone levels in rams. $J$. Endocrinology, 60: 101-106.

Lavara, R., I. David, E. Mocé, M. Baselga, and J.S. Vicente (2013). Environmental and male variation factors of freezability in rabbit semen. Theriogenology, 79: 582-589.

Marai, I. F., K. A. El-Masry and A. S. Nasr (1994). Heat stress and its amelioration with nutritional, buffering, hormonal and physical techniques for New Zealand White rabbits maintained under hot summer conditions of Egypt. $1^{\text {st }}$ Int. Conf. Rabbit Prod. in Hot Climates, 6-8 September, 1994, Cairo, Egypt, pp. 475-487.

Marai, I.F.M., Ayyat, M.S. and Abd El-Monem, U.M. (2001). Growth performance and reproductive traits at first parity of New Zealand White female rabbits as affected by heat stress and its alleviation under Egyptian conditions. J. Trop. Anim. Health Prod., 33: 1-12.

Marai, I.F.M., M.S. Ayyat and Abd El-Monem U.M. (2006). Growth performance, blood components and slaughter traits of New Zealand White male growing rabbits as affected by dietary supplementation with calcium, sodium or potassium, in subtropical Egypt. Tropical and Subtropical Agroeco systems, 6: 149-155.

McDowell, L.R. (2000). Vitamins in Animal and Human Nutrition. Iowa State Press, Iowa, USA.

Meshreky Samia Z., Mervat M. Arafa, Abo-Warda M. A. (2005). Evaluation of male capabilities in V-line, Baladi Red Rabbits and their cross under the Egyptian environmental conditions. In Proc.: 2nd Sci. Conf. Anim. Prod. Res. Inst., Egypt, Sep., 681-693.

NRC (1977). National Research Council: Nutrient Requirements of Rabbits. 2nd Revised Edition, National Academy of Sciences, Washington, DC. USA.

Ogunjimi, L.A.O., Ogunwande, G.A. and Osunade, J.A. (2008). Rabbit weight gain, feed efficiency, rectal temperature and respiration rate as affected by building thermal environment in the humid tropical climate of Southwestern Nigeria. Agric. Engine. Inter., 10: 1-14. 
Okab, A. B., S.G. El-Banna, and A. A. Koriem (2008). Influence of environmental temperatures on some physiological and biochemical parameters of New-Zealand rabbit males. Slovak J. Anim. Sci., 41:12-19.

Ondruska, L., J. Rafay, A.B. Okab, M.A. Ayoub, A.A. Al-Haidary, E.M. Samara, V. Parkanyi, L. Chrastinova1, R. Jurcik1, P. Massanyi, N. Lukac, and P. Supuka (2011). Influence of elevated ambient temperature upon some physiological measurements of New Zealand White rabbits. Veterinarni Medicina, 56, 2011 (4): 180-186.

Osman Noha A.M. (2005). Influence of supplemental probiotic on immunological, hematological and productive performance in growing rabbits. M. Sc. Thesis, Agric. Fac., Cairo Univ., Egypt.

Rafai, P. and Z. Papp (1984). Temperature requirement of rabbit does for optimal performance. Archiv Fur Exprimntalle Veterinarmedizin, 38 : 450-457.

Roca J., Martinez S., Orengo J., Parrilla I., Vazquez J.M., and Martinez E.A. (2005). Influence of constant long days on ejaculate parameters of rabbits reared under natural environment conditions of the Mediterranean area. Livestock Production Sci., 94, 169-177.

Safaa H.M., Emarah M.E., and Saleh N.F.A. (2008). Seasonal effects on semen quality in black Baladi and White New Zealand rabbit bucks. World Rabbit Sci., 16: 13 - 20.

Sherines R.J., and Howards S.S. (1978). Male infertility. Campbell's Urology. 4th ed. Philadelphia, Pa:W. B. Saunders Co, 715.

SPSS (2012). SPSS User's Guide Statistics Version 19., SPSS Inc., USA.

Sunmonu, T.O. and Oloyede O.B. (2007). Biochemical assessment of the effects of crude oil contaminated catfish (Clarias gariepinus) on the hepatocytes and performance of rat. African Journal of Biochemistry Research, 1: 083-089.

Suttle, N.F. (2010). The mineral nutrition of livestock. 4th Edition, CAB International Publishing, UK.

Tietz, N.W. (1986). Fundamentals of clinical chemistry, WB Saunders Company, Philadelphia. pp. 723.

Warren J.E., and Gregory G. (2005). Statistical Methods in Bioinformatics: An Introduction (Statistics for Biology and Health). Springer Science press, New York, USA.

Wittorf, E. K., C. E. Heird, J. M. Rakes and Z. B. Johnson (1988). Growth and reproduction of nutrient restricted rabbits in a heat stressed environment. J. Appl. Rabbit Res., 11: 87-92.

Yousef M.I., Kamel K.I., Esmail A.M., and Baghdadi H.H. (2004). Antioxidant activities and lipid lowering effects of isoflavone in male rabbits. Food Chem. Toxicol., 42, 1497-503. 


\section{تثئير التداخل بين إضافة مسحوق الأراك للعليقة وموسم الإنتاج على الأداء الفسيولوجي قبل وبعد النضج الجنسى لذكور الأرانب الأبتاج}

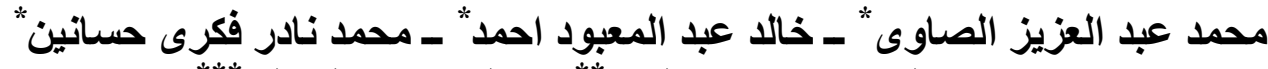

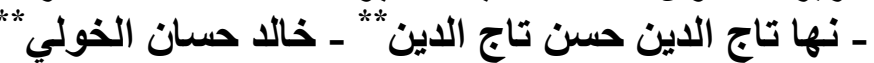

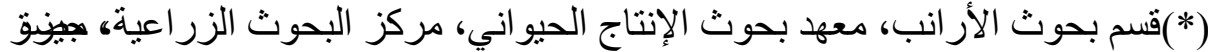

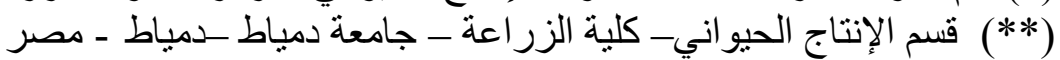

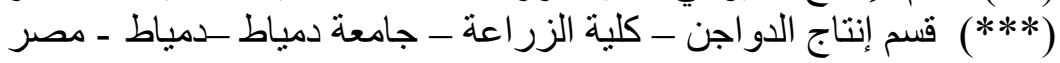

تهدف هذه الدارسة إلى تقييم تأثير إضافة الأر الك للعليقة وموسم الإنتاج و التداخل بينهما على الإلى

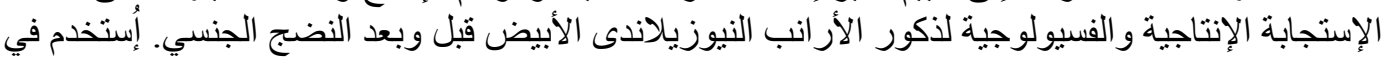

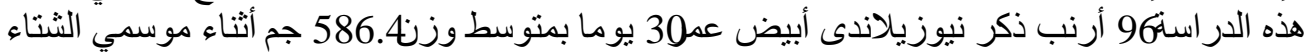

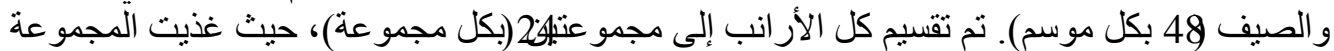

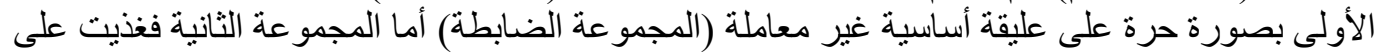

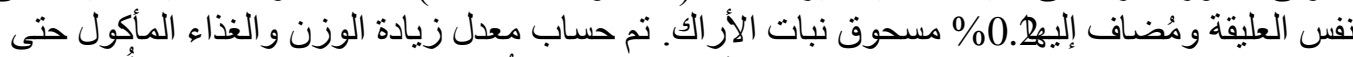

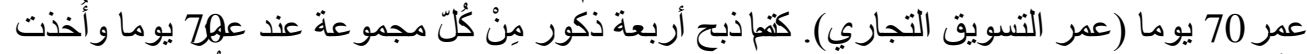

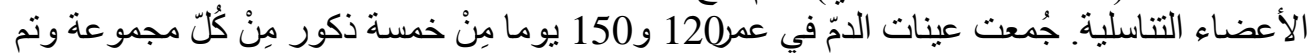

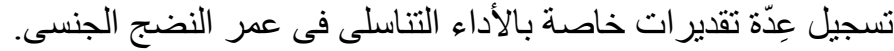

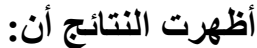

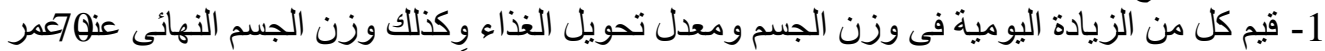

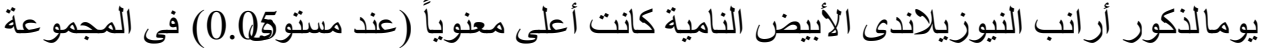

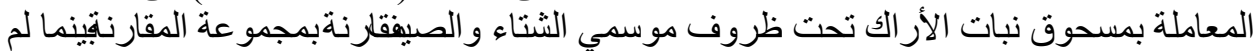

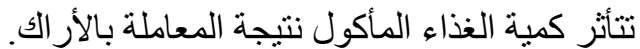

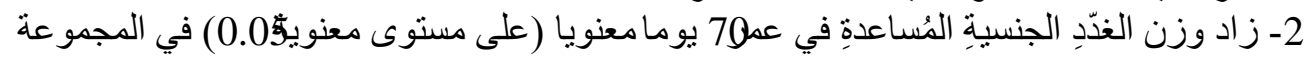

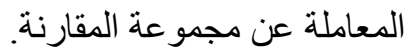

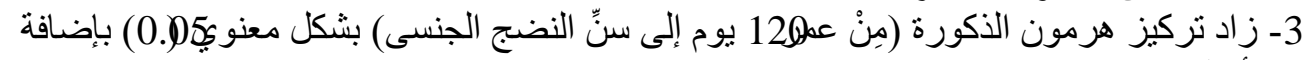

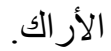

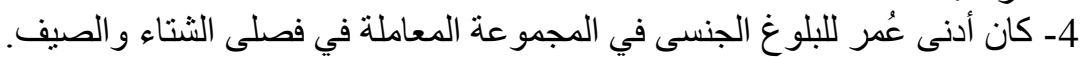

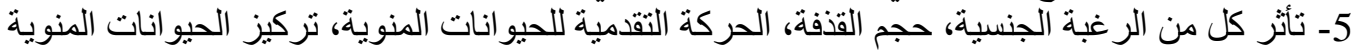

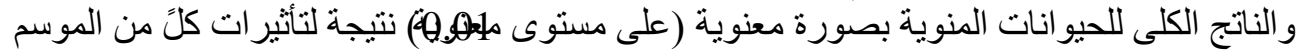

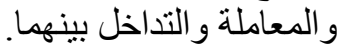
6- أدت إضافة مسحوق الأر الك للأر انب في موسم الصيف إلى إقتراب نتائجها من الأرانب الغير معاملة

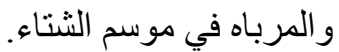

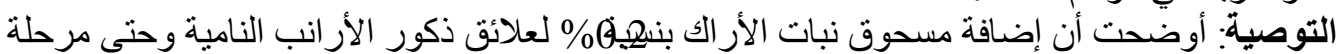

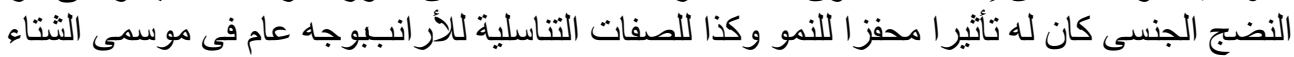
و الصيف وقد ظهرت أهمية ذللك جلئ فصل الصيف. 